\title{
МЕТОДИКА ІНТЕРАКТИВНОГО НАВЧАННЯ МАЙБУТНІХ УЧИТЕЛІВ МУЗИЧНОГО МИСТЕЦТВА НА ЗАНЯТТЯХ ХОРОЗНАВСТВА
}

\begin{abstract}
Анотація. У статті обгрунтовано методику інтерактивного навчання майбутніх учителів музичного мистецтва на заняттях хорознавства. Здійснений аналіз пріоритетних напрямків диригентсько-хорової підготовки здобувачів вищої освіти. Актуалізована проблема необхідності осучаснення методики викладання хорознавства засобами інтерактивного навчання. Обірунтовано інтерактивні підходи до навчання майбутніх учителів музичного мистецтва. Розкрито зміст, методику і форми інтерактивного навчання хорознавства у закладах вищої освіти. Охарактеризовано ефективні форми проведення лекційних, семінарських і практичних занять з хорознавства. Доведено, що інтерактивне навчання на заняттях хорознавства забезпечуе якість теоретичної підготовки майбутніх учителів музичного мистецтва, сприяе формуванню досвіду активного засвоєння змісту майбутньої профресійної діяльності у взаємозв’язку із практичними навичками.
\end{abstract}

Ключові слова:методика, інтерактивне навчання, майбутній учитель музичного мистецтва, хорознавство.

Sofronii Zoya, Churikova-Kushnir Olha

Yuriy Fedkovych Chernivtsi National University

\section{INTERACTIVE TEACHING METHODS OF FUTURE MUSIC ART TEACHERS IN CHOIR SCIENCE CLASSES}

Summary. The interactive teaching methods of future music art teachers in choir science classes is substantiated in this article. The analysis of priority directions of native conductorial and choral training of higher education applicants is carried out. The problem of the need to modernize the methods of studying choir science, in particular, by means of interactive teaching, is actualized. The essence and content of interactive teaching of future music art teachers in higher education institutions are determined. Interactive teaching is considered as a special form of organization of cognitive activity of students, which helps to strengthen motivation to study the discipline, the development of critical thinking, communicative competence, skills of own finding and processing of information, ensuring constant contact with the teacher. Interactive approaches to the teaching of future music art teachers are substantiated. The content, methods and forms of interactive teaching of choir science in higher education institutions are revealed. Specified purpose, task and meaningful content modules of studying course of choir science in training for future teachers of music art. The basic rules of conducting interactive classes are stipulated. Provided detailed algorithm of implementation methods and forms of interactive studying at choir science lessons. Effective forms of conducting lectures are characterized, including binary lectures, video lectures, mini-lectures, problem lectures, lectures with planned mistakes, lectures-press conferences. The methods of conducting seminars and practical classes in choir science are specified, in particular the arsenal of interactive teaching methods: business game, case method, collective solution of creative tasks, work in small groups (analysis and studying of children's choral works), viewing and discussion of educational videos. It is proved that interactive teaching in choir science classes provides the quality of theoretical training of future music art teachers, contributes to the formation of experience of active learning of the content of future professional activity in context with practical skills, the development of professional reflection.

Keywords: methods, interactive teaching, future music art teacher, choir science.

$\Pi^{\circ}$ остановка проблеми. Суспільні зміни, спричинені світовими перетвореннями, торкнулися усіх сфер людської діяльності, а особливо освітніх процесів. Реформування вищої освіти України в умовах дистанційного навчання майбутніх фохівців зумовило інтенсивний пошук ефективних методів і форм викладання, які забезпечують можливість інтерактивного спілкування із здобувачами. Адже традиційна організація навчального процесу, яка здійснюеться шляхом односторонньої трансляції викладачем інформації і подальшого їі відтворення студентами на сучасному етапі розвитку освіти, $\varepsilon$ неефективною. Удосконалення організації процесу навчання передбачае широке використання активних та інтерактивних форм і методів навчання. Осучаснення потребують методичні підходи до фахової підготовки майбутніх учителів музичного мистецтва, зокрема у викладанні обов'язкових професійних дисциплін. У даному аспекті набувае актуальності проблема методичного забезпечення інтерактивного навчання майбутніх учителів музичного на заняттях хорознавства - навчальної компоненти, яка забезпечуе засвоєння здобувачами системи базових знань про хорове мистецтво. Саме інтерактивність у викладанні зазначеного курсу сприятиме формуванню у студентів здатності застосовувати теоретичні знання у практичній роботі з дитячими хоровими колективами.

Аналіз останніх досліджень і публікацій. Аналіз наукових праць з фахової підготовки майбутніх учителів музичного мистецтва свідчить про значний інтерес дослідників до оновлення змісту диригентсько-хорової підготовки: оновленню змісту навчальних програм; видавництву навчально-методичних посібників; уведенню нових лекційних і практичних курсів. Так, методичну цінність становлять посібники з хорознавства Т. Смирнової, О. Сбітневої, авторського 
колективу Є. Плющик, В. Омельчук, В. Федорченко. Значний поступ у вдосконаленні змісту диригентсько-хорової підготовки майбутніх учителів музичного мистецтва спричинило введення до освітніх програм вітчизняних закладів вищої освіти курсів: шкільного хорознавства (В. Доронюк, Ж. Зваричук), методики роботи з дитячим хоровим колективом (С. Світайло, I. Ярошенко), шкільного практикуму (Л. Бірюкова), та інших.

Переважна більшість наукових праць останніх років присвячена питанням розробки методичних засад диригентсько-хорової підготовки (Чжан Лу) й готовності майбутніх учителів музичного мистецтва до диригентсько-хорової діяльності (Д. Бондаренко), підготовки іноземних студентів до керівництва хоровими колективами (Ма Сюй), формування методичної компетентності на заняттях з хорового диригування (Л. Теряєва). акмеологічної спрямованості процесу фрахової підготовки майбутніх учителів музичного мистецтва (А. Козир).

Виділення невирішених раніше частин загальної проблеми. Окремі дослідження у галузі теорії і методики музичного навчання присвячені питанням підготовки студентів до інтерактивного навчання музики початкових шкіл Китаю (Чень Чень) та творчої інтерсуб'єктної взаємодії вчителя музики 3 дитячими вокальнохоровими колективами (Чжу Чжень). Натомість зазначені праці лише частково вирішують проблему впровадження методів інтерактивного навчання студентів. Недостатньо дослідженими залишаються питання розробки методики інтерактивного навчання майбутніх учителів музичного мистецтва на заняттях хорознавства.

Мета статті. Мета статті полягає у висвітленні й обгрунтуванні методики інтерактивного навчання майбутніх учителів музичного мистецтва на заняттях хорознавства.

Виклад основного матеріалу дослідження. Впровадження інтерактивного навчання в освітній процес вищої школи передбачає зміну методичних стереотипів щодо підготовки майбутніх фахівців. Теоретичні засади проблеми інтерактивного навчання набули розробки у працях зарубіжних та українських науковців. Так, питання застосування інтерактивних методів навчання розкриті у працях Н. Двулічанської, О. Коберник, О. Коротаєва, М. Косолапової, В. Мельник, Г. Мітіної, Л. Пироженко, О. Пометун, О. Сікарчук, С. Стельмах, Ю. Фокіна. Методична дієвість інтерактивного навчання забезпечуе чітке структурування змісту і форми навчальної дисципліни, що стимулюе інтерес здобувачів до предмету вивчення, пізнавальну ініціативу і самостійність. За визначенням Ю. Фокіна, інтерактивні методи навчання оріентовані на більш широку взаемодію, не лише викладача зі студентами, але й студентів між собою [7, с. 12].

«Хорознавство» як навчальний предмет був уведений до змісту підготовки здобувачів диригентсько-хорового факультету Московської консерваторії. Розробником курсу став теоретик i хоровий диригент П. Чесноков, який у 1940 році написав навчальний посібник «Хор і управління ним». Це була перша методична праця, в якій розглядались питання теоретичних засад хорового виконавства та практичної роботи з хоровим колективом. Хорознавчий контент навчального курсу змінювався у відповідності до розвитку хорового мистецтва, виконавських традицій та суспільних потреб. Змінювались та удосконалювались методи викладання.

У системі фахової підготовки майбутніх учителів музичного мистецтва хорознавство е важливим освітнім компонентом, оскільки передбачае формування у студентів системи базових знань про хорове мистецтво, історію становлення і розвитку хорознавства як науки про хорове виконавство, теоретичні основи хорового виконавства, методичні засади роботи з дитячими хоровими колективами.

Навчальна дисципліна "Хорознавство» спрямована на формування у здобувачів фрахових компетентностей, що забезпечують якісну підготовку майбутніх учителів музичного мистецтва до практичної роботи 3 хоровими дитячими колективами закладів загальної середньої та позашкільної освіти. Основні завдання курсу полягають в:

- ознайомленні майбутніх фрахівців з історією розвитку хорового мистецтва й освіти;

- засвоєнні здобувачами системи теоретичних знань про хоровий колектив як вокальну організацію, елементи вокально-хорової звучності, специфіку вокальної роботи в хорі, гігіену й охорону співацького голосу;

- ознайомленні здобувачів із особливостями письмової нотації хорових творів, можливостями застосування цифрових технологій у вокальнохоровій роботі;

- формуванні навичок музично-педагогічного аналізу й ціннісного ставлення до хорових творів;

- оволодінні методикою організації, управління й практичної роботи з дитячими хоровими колективами у процесі урочної, позаурочної і позашкільної музичної освіти.

Засвоення змісту навчальної дисципліни залежить від мотивації майбутніх фахівців й творчого підходу викладача до хорового репертуару, вмілого застосування різних методів навчання. На кафедрі музики Чернівецького національного університету імені Юрія Федьковича широкого впровадження набули методи інтерактивного навчання. Саме методи і форми інтерактивного навчання забезпечують багатосторонність комунікації в освітньому процесі, коли викладач у своїй роботі використовуе діалогічні методи спілкування, спільний пошук «істини», різноманітні творчі завдання. Інтерактивне навчання здобувачів організоване так, що всі вони залучаються до процесу пізнання, розуміння і рефлексії того, що вони знають і про що думають. У порівнянні із традиційними формами проведення занять, при інтерактивному навчанні змінюеться взаемодія викладача і здобувача: мета викладання передусім полягає у створенні педагогічних умов для вираження ініціативи та активності студентів.

Саме слово інтерактивний («Inter» означае «взаемний», «асt» - діяти) - означае взаемодіяти, знаходитись в режимі бесіди, діалозі з кимось (або чимось). За переконаннями Н. Двулічанської, «інтерактивний метод можна розглядати як найбільш сучасну форму активних методів» $[1$, c. 3]. За визначенням М. Косолапової, інтерактивне навчання - це «спеціальна форма орга- 
нізації пізнавальної діяльності, яка здійснюеться у процесі спільної діяльності студентів, при якому усі учасники взаємодіють один 3 одним, обмінюються індрормацією, спільно вирішують проблеми, моделюють ситуації, оцінюють власну поведінку й дії інших, занурюються в реальну атмосфреру ділового співробітництва з вирішення проблеми» [3, с. 7].

У ході діалогового навчання студенти навчаються критично мислити, вирішувати складні завдання на основі аналізу відповідної інформації та пропонованої ситуащії, враховувати альтернативні думки, приймати виважені рішення, брати участь у дискусіях, спілкуватися з іншими людьми. Інтерактивні методи і форми проведення занять забезпечують результативність навчання: розвиток мислення й активно-пізнавальної діяльності; залучення студентів до процесу пізнання, освоєння нового матеріалу в якості активних учасників; розвиток умінь і навичок аналізу, критичного мислення; посилення мотивації до вивчення дисципліни; створення сприятливої творчої атмосфери на заняттях; розвиток комунікащійних компетенцій студентів; скорочення аудиторних годин і збільшення об'єму самостійної роботи; розвиток умінь і навичок володіння сучасними технічними засобами навчання і обробки інформації; формування умінь і навичок самостійного знаходження інформації й визначення рівня іï достовірності; гнучкість і доступність процесу навчання - підключення до освітніх ресурсів і комп'ютерних програм; використання електронних тестів (поточних, рубіжних, проміжних); забезпечення постійного, а не епізодичного (за розкладом) контакту студентів з викладачами.

За визначенням М. Косолапової, особливість інтерактивних методів навчання передбачає високий рівень взаємоспрямованої активності суб'єктів, емоційної, духовної єдності учасників [3, с. 106]. 3 цією метою на заняттях хорознавства доцільно організовувати парну й групову роботу здобувачів, впроваджувати дослідницькі проєкти, рольові ігри, організовувати роботу 3 документами, відео та аудіо-записами хорових творів, різними джерелами інформації, використовувати творчі завдання.

У процесі проведення лекційних і семінарських занять 3 хорознавства доцільності набувають інтерактивні підходи до навчання майбутніх учителів музичного мистецтва, серед яких найбільш ефективними є: творчі завдання; навчальні ігри (рольові, імітаційні, ділові); освітньо-мистецькі й культурно-просвітницькі проєкти, позааудиторні методи навчання (змагання, інтерв'ю, фрільми, концерти); вивчення й закріплення нового матеріалу (інтерактивна лекція, робота 3 відео- й аудіо-матеріалами, «студент в ролі викладача», «кожен навчає іншого»); тестування; розминка, зворотній зв'язок; дистанційне навчання; обговорення складних і дискусійних питань та проблем хорового виконавства (займи позицію); вирішення проблем («мозковий штурм», «снігова куля»); тренінги мистецького вправляння.

Навчальна програма 3 хорознавства кафедри музики Чернівецького національного університету імені Юрія Федьковича передбачає засвоєн- ня майбутніми учителями музичного мистецтва трьох змістових модулів: 1) Історія розвитку хорового мистецтва; 2) Теоретичні основи хорового виконавства; 3) Методичні засади роботи 3 дитячим хоровим колективом.

Однією із основних форм вивчення змісту навчальної дисципліни є лекція. В енциклопедичному словнику освітніх технологій «лекція (від лат. lectio - читання) - трактуеться, як процес передачі великій аудиторії (групі) значного обсягу систематизованої інфрормації в усній формі [4, с. 110]. С. Стельмах зазначає, що лекція - «найбільш економний спосіб передачі й засвоєння навчальної інформації, тобто інтелектуальної культури поколінь, вміщеної в рамках педагогічних форм навчання» [6, с. 186]. Відтак, лекція забезпечуе органічну єдність методу навчання і форми його організації, що полягає у систематичному, послідовному, монологічному викладенні лектором теоретичного навчального матеріалу.

Реалізуючи підходи інтерактивного навчання у засвоєнні змісту навчального курсу, актуальним $є$ використання бінарних лекцій, відео-лекцій, міні-лекцій, проблемних лекцій, лекцій із запланованими помилками, лекційпрес-конференцій. Так, бінарні лекції передбачають виклад матеріалу у формі діалогу двох викладачів, або ж викладача і відомого діяча хорового мистецтва. Вимогою до проведення таких лекцій-діалогів $є$ демонстрація культури спілкування, долучення студентів до обговорення змісту навчальної теми. На лекційних заняттях із застосуванням інтерактивних форм здобувачі повинні бути готовими до участі в міні-дискусіях, вміти задавати питання лектору і відповідати на його питання. Такий підхід активізуе роботу студентів на лекціях, які перестають бути виключно монологом викладача.

Едективність відео-лекцій полягає у можливості їх багаторазового перегляду у зручний для здобувачів час. Відео-лекція дає можливість подати чітко структурований матеріал, продемонструвати презентації, таблиці, фоото, нотні партитури, відеозаписи. Викладач має можливість зафіксувати кращий варіант своєї доповіді. Розроблена і записана на відео серія таких лекцій едективно використовується у процесі дистанційного, змішаного та заочного навчання майбутніх учителів музичного мистецтва, а також для повторення пройденого матеріалу.

Засвоєння теоретичних тем 3 хорознавства забезпечують міні-лекції. Методика їх проведення передбачає опитування студентів перед повідомленням необхідної інформації. Викладач застосовуе мозковий штурм або рольову гру, пов'язану із наступною темою. Такий підхід дозволяе викладачу вияснити що саме знають здобувачі, встановити ступінь ї обізнаності задля уникнення повторення вже відомої для них інфрормації. Лектор повинен зосередитись на тих питаннях, які є актуальними й новими. Матеріал викладати дотримуючись принципу доступності, надавати точні визначення для кожного терміну і поняття. Після представлення конкретних фрактів, тверджень, зразків музичної інфрормації, викладач пропонуе студентам долучитися до обговорення питань, висловлення власного ставлення до них. До прикладу: «Як ви вважаєте?», 
«Як пропонуєте це зробити з конкретною віковою групою?», «Як ви вважаєте, до чого це може призвести?». Перед тим, як перейти до обговорення наступного питання необхідно зробити підсумок, переконатися у правильності його сприйняття i розуміння. Після завершення виступу викладач повинен відповісти на запитання слухачів, а також обсудити, як отримана інформація може бути використана у педагогічній практиці, у роботі з учнями.

Кращому засвоєнню нового матеріалу сприяє впровадження проблемних лекцій. Іх суть полягає у тому, що нове знання повідомляється через проблемний виклад матеріалу. Так, процес пізнання студентів набуває ознак дослідницької діяльності, що реалізуеться через діалог і співпрацю з викладачем. Зміст навчальної проблеми викладач розкриває шляхом організації пошуку її рішення або ж вдаючись до аналізу традиційних і сучасних поглядів науковців, мистецтвознавців, педагогів-практиків, й формування єдиної позиції щодо їі трактування.

Значно активізують увагу студентів лекції із запланованими помилками. Така форма проведення лекцій дозволяе розвинути у здобувачів уміння оперативно аналізувати професійні ситуащіі, виступати в ролі експертів, опонентів, вирізняти невірну і неточну інформацію. Для впровадження лекцій із запланованими помилками на заняттях з хорознавства необхідно володіти відповідною методикою. Так, на попередньому занятті викладач повідомляе тему наступної лекції, кількість очікуваних помилок, надаються матеріали для попереднього ознайомлення із заявленою темою (посилання на джерела, тощо). Перед проведенням лекції здобувачів розподіляють на підгрупи (3-5 осіб). При цьому виклад матеріалу рекомендують поділити на кілька підрозділів, після кожного провести обговорення (2-3 хвилини), зробити висновок щодо наявності помилок та їх кількості у даному підрозділі. Кількість зазначених помилок фріксуеться у кожній групі.

Виклад усього матеріалу рекомендовано завершити за 10 хвилин до закінчення заняття. Представникам підгруп пропонують озвучити усі визначені ними факти помилок і записати їх на дошці. Іншим підгрупам пропонують спростувати заявлені фракти або обгрунтувати наслідки цих помилок, даючи можливість студентам зрозуміти рівень володіння темою. На завершення заняття необхідно вказати на правильні відповіді та відзначити ті підгрупи, в яких найбільший відсоток вірних відповідей. Заохоченням можуть бути бали рейтингової системи, які виставляють за засвоєння теми.

Ефективне стимулювання пізнавальної діяльності майбутніх учителів музичного мистецтва у процесі ознайомлення із теоретичними основами хорового виконавства доцільно здійснювати на лекціях-прес-конференціях. У педагогічній практиці вони проводяться як науково-практичні заняття, із наперед визначеною проблематикою і серією підготовлених студентами доповідей тривалістю 5-10 хвилин. Кожен виступ представляє собою логічний завершений текст, добірка яких дозволяе розглянути досліджуване питання $з$ різних сторін. В кінці такої лекції викладач підсумовує результати само- стійної роботи і виступів здобувачів, доповнюе і уточнюе запропоновану інформацію, формулюе остаточні судження.

При розробці алгоритму проведення інтерактивних занять необхідно керуватись основними правилами:

1. Залучати до процесу обговорення усіх учасників освітнього процесу, використовуючи відповідні технології.

2. Забезпечувати психологічну готовність учасників. Корисними є розминки, постійне заохочення, можливість самореалізації.

3. Враховувати, що якість навчання залежить від кількості учасників, оптимальна кількість 25 осіб.

4. Використовувати приміщення, в якому учасникам легко було б переміщатися для роботи у великих і малих групах.

5. Дотримуватись чіткої фріксації процедур і регламенту.

6. Проявляти уважність до розподілу учасників семінару на групи. На початкових етапах його необхідно вибудовувати на добровільній основі. Далі доцільно керуватись принципом випадкового вибору [5, с. 37].

На семінарських заняттях 3 хорознавства доцільно застосовувати такий арсенал методів інтерактивного навчання, як: ділова гра, кейсметод, колективне вирішення творчих завдань, робота в малих групах (аналіз і вивчення дитячих хорових творів), перегляд і обговорення навчальних відеофільмів.

Впровадження ділових ігор забезпечуе засвоєння методів і прийомів розучування хорових творів. Оскільки ділова гра є «засобом моделювання різноманітних умов професійної діяльності шляхом пошуку нових способів її виконання вона імітуе різні аспекти професійної активності і соціальної взаємодії» [2, с. 62]. Гра також є методом ефективного навчання, оскільки нівелює протиріччя між абстрактним характером навчальної ситуації та реальними умовами професійної діяльності.

Ділові ігри як метод засвоєння знань з хорознавства можуть застосовуватись з метою: формування пізнавальних професійних мотивів та інтересів; розвитку системного мислення; передачі цілісного уявлення про професійну діяльність; навчання колективній практичній роботі, фрормування умінь і навичок соціальної взаємодії і спілкування, навичок спільного й індивідуального прийняття рішень; виховання відповідального ставлення до справи, поваги до сощіальних цінностей і установок колективу; оволодіння методами моделювання, педагогічного проектування.

Для засвоєння методів розучування дитячих хорових творів майбутніх учителів музичного мистецтва необхідно долучати до виконання ділових ігор різного виду, які передбачають: тренінг окремої навички: тренінг комплексу навичок; демонстращії навичок; демонстрації типових помилок. У такий спосіб використання ділових ігор сприяе розвитку комунікативних навичок, навичок вирішення проблем, опрацюванню різних варіантів власної поведінки у проблемних ситуаціях. Саме під час ділових ігор у процесі навчання імітуються реальні умови професійної діяльності, відпрацьовуються конкретні специ- 
фрічні музично-педагогічні ситуащії, моделюється відповідний педагогічний музично-виконавський процес.

Кейс-метод (від англійського case - випадок, ситуація) - удосконалений метод аналізу конкретних навчальних ситуацій, метод активного проблемно-ситуативного аналізу [4, с. 416]. Переваги застосування на семінарських заняттях 3 хорознавства полягають у забезпеченні системного підходу до вирішення педагогічної проблеми, виробленні критеріїв знаходження оптимальних рішень, поєднанні теоретичного тезаурусу з реальною практичною ситуацією, відсутності ризику для учасників гіпотетичної ситуащї.

Метод конкретних ситуацій (case-study) належить до неігрових імітаційних активних методів навчання. Під час аналізу конкретних навчально-педагогічних ситуацій у майбутніх учителів музичного мистецтва розвиваються навички групової, командної роботи, що розширює можливості вирішення типових проблем. До прикладу, аналізуючи конкретну педагогічну ситуащію, студент повинен її зрозуміти, оцінити, визначити чи $є$ в ній проблема, визначити свою роль у вирішенні проблеми і виробити доцільну лінію поведінки. Методисти рекомендують метод конкретних ситуацій розподіляти на етапи: підготовчий, ознайомлювальний, аналітичний та ігровий $[1 ; 5]$.

Метод аналізу конкретних ситуацій нараховує більше 30 модифрікацій, однією з яких є кейсметод. Методична цінність кейс-методу полягає в тому, що він концентрує в собі технологію «створення успіху». Характерним для нього є активізація здобувачів, стимулювання їх успіху, заохочення досягнень учасників. Відчуття успіху є рушійною складовою методу, сприяе формуванню стійкої позитивної мотивації й пізнавальної активності.

Реалізація методики здійснюеться у відповідності до визначених етапів: а) етап введення у досліджувану проблему; б) аналіз ситуацї; в) етап презентації; г) етап загальної дискусії; д) етап підведення підсумків. За переконанням О. Сікарчук, навчальний кейс повинен відповідати таким вимогам: «відповідати конкретній меті; містити відповідний рівень складності; ілюструвати кілька аспектів; бути актуальним; ілюструвати типові ситуащії; розвивати аналітичне мислення; провокувати дискусії; мати кілька рішень» [5, с. 48].

Метод колективного вирішення творчих завдань вимагає від студентів не просто відтворення інформащії, а прояву творчості. У результаті його впровадження здобувачі повинні віднайти «правильне» спільне рішення, основане на власному досвіді й досвіді своїх колег. Це може бути створення художньої інтерпретації хорового твору, спільна розробка афріші, програми концертного виступу дитячого хору, вивчення і виконання хорової пісні, тощо. У џьму контексті даний метод потребуе обов'язкового творчого наставництва, забезпечення співпраці початківців і викладача.

У доборі творчих завдань необхідно дотримуватись таких критеріїв: завдання повинні бути практичними і корисними; передбачати відсутність однозначного рішення; викликати інтерес; мати зв'язок із життям; максимально відповідати цілям навчання. Якщо здобувачі не звикли творчо працювати, необхідно поступово вводити прості завдання, далі ускладнювати їх зміст.

Робота в малих групах на заняттях з хорознавства передбачає можливість участі усіх студентів у роботі, практикувати навички співтворчості і співробітництва, міжособистісного спілкування (уміння активно слухати, виробляти загальну думку, вирішувати дискусійні питання).

Інтерактивний метод перегляду й обговорення навчальних і науково-пізнавальних відеофрільмів відповідного змісту необхідно використовувати на будь-якому етапі занять у відповідності до тематики змістових модулів курсу. Так, одним із завдань самостійної роботи студентів 3 хорознавства $є$ перегляд та аналіз документального фрільму про видатного українського композитора «Артемій Ведель. Справа божевільного». Перед показом фільму здобувачам ставлять кілька ключових питань, які стануть основою для подальшого обговорення. При спільному перегляді можна зупиняти відео й проводити дискусію конкретних кадрів (моментів). Наприкінці заняття необхідно обов'язково підвести висновки й озвучити отримані судження.

Основна мета використання відеофільмів полягае в організації процесу вивчення теоретичного змісту в інтерактивному режимі (вивчення біографії, композиторської творчості, особистісних характеристик митця, тощо). Завдання методу перегляду й обговорення відеофільму передбачають: удосконалення способів пошуку, обробки і представлення нової індрормації; розвиток комунікативних навичок; актуалізації та візуалізації змістового наповнення лекції.

Використання методів інтерактивного навчання майбутніх учителів музичного мистецтва на заняттях хорознавства змінюе також роль самого викладача. Він перестає бути центральною фрігурою в освітньому процесі, а лише займається його організацією і регуляцією, підбирає заздалегідь завдання і питання, теми для обговорення в групах, надає консультації, контролює час і порядок виконання наміченого плану.

Висновки і пропозиції. Отже, застосування методики інтерактивного навчання майбутніх учителів музичного мистецтва на заняттях хорознавства передбачає застосування цілого арсеналу ефективних інтерактивних методів (бінарних лекцій, відео-лекцій, міні-лекцій, проблемних лекцій, лекцій із запланованим помилками, лекцій-прес-конференцій, ділових ігор, кейс-методу, колективного вирішення творчих завдань, роботи в малих групах, перегляду й обговорення навчальних відеофільмів) й дозволяє здобувачам вищої освіти у процесі навчання набути досвіду активного засвоєння змісту майбутньої професійної діяльності у взаємозв'язку із практикою, розвинути редрлексію як майбутнього фрахівця, засвоїти новий досвід профресійної взаємодії 3 профресіоналами-практиками. Подальшої розробки потребує методика інтерактивного навчання майбутніх учителів музичного мистецтва у процесі засвоення музично-виконавських дисциплін, зокрема практичних занять 3 диригування, вокалу, музичного інструменту. 


\section{Список літератури:}

1. Двуличанская Н.Н. Интерактивные методы обучения как средство формирования ключевых компетенций. Наука и образование: электронное научно-техническое издание, 2011. URL: http://technomag.edu.ru/doc/172651

2. Інтерактивні технології навчання: теорія, практика, досвід, метод / Укл. О. Пометун, Л. Пироженко. Київ : $\mathrm{A \Pi H}, 2002.135 \mathrm{c}$

3. Косолапова М.А. Технологческие подходы в организации продессиональной подготовки к педагогической деятельности в высшей школе. Томский гос. пед. ун-т. Томск, 2007. 177 с.

4. Селевко Г.К. Энциклопедия образовательных технологий : в 2 т. Москва : НИИ школьных технологий, 2006. T. $1.816 \mathrm{c}$

5. Сікарчук O.I. Інтерактивні методи навчання у вищій школі : навчально-методичний посібник. Київ : Таксон, 2006. $88 \mathrm{c}$.

6. Стельмах С. Використання інтерактивних методів навчання в процесі проведення лекційних занять. Психолого-педагогічні проблели сільської школи. 2011. № 39(2). С. 184-190.

7. Фокин Ю.Г. Преподавание и воспитание в высшей школе: методология, цели и содержание, творчество : учеб. пособие для студ. высш. учеб. заведений. Москва : Издательский центр «Академия», 2002. 224 с.

\section{References:}

1. Dvulichanskaya N.N. (2011) Interaktivnyie metody obucheniya kak sredstvo formirovaniya klyuchevyih kompetentsiy [The interactive teaching methods as means of forming core competencies]. Nauka i obrazovanie. Retrieved from: http://technomag.edu.ru/doc/172651 (in Russian)

2. Interaktyvni tekhnolohii navchannia: teoriia, praktyka, dosvid, metod (2002) [The interactive teaching technologies: theory, practice, experience, method] / Ukl. O. Pometun, L. Pyrozhenko. Kyiv: APN, p. 135. (in Ukrainian)

3. Kosolapova M.A. (2007) Tehnologcheskie podhodyi v organizatsii professionalnoy podgotovki k pedagogicheskoy deyatelnosti $\mathrm{v}$ vyisshey shkole [Technological approaches in the organisation of professional training for teaching in high education]. Tomskiy gos. ped. un-t. Tomsk, p. 177. (in Russian)

4. Selevko G.K. (2006) Entsiklopediya obrazovatelnyih tehnologiy: v 2 t. [Encyclopedia of educational technologies]. Moscow: NII shkolnyih tehnologiy, t. 1, p. 816. (in Russian)

5. Sikarchuk O.I. (2006) Interaktyvni metody navchannia u vyshchii shkoli: navchalno-metodychnyi posibnyk [The interactive teaching methods in high school: training manual]. Kyiv: Takson, p. 88. (in Ukrainian)

6. Stelmakh S. (2011) Vykorystannia interaktyvnykh metodiv navchannia v protsesi provedennia lektsiinykh zaniat [The use of interactive teaching methods in the course of lectures]. Psykholoho-pedahohichni problemy silskoi shkoly, no. 39(2), pp. 184-190. (in Ukrainian)

7. Fokin Yu.G. (2002) Prepodavanie i vospitanie v vyisshey shkole: metodologiya, tseli i soderzhanie, tvorchestvo [Teaching and education in high school : methodology, purpose and content, creation]: ucheb. posobie dlya stud. vyissh. ucheb. Zavedeniy. Moscow: Izdatelskiy tsentr "Akademiya», p. 224. (in Russian) 